ORIGINAL ARTICLE

\title{
Peritoneovenous shunting is an effective treatment for intractable ascites
}

\author{
P Sooriakumaran, H F McAndrew, E M Kiely, L Spitz, A Pierro
}

Postgrad Med J 2005;81:259-261. doi: 10.1136/pgmj.2004.023663

See end of article for authors' affiliations .....................

Correspondence to: Dr P Sooriakumaran, Flat 15 Andhurst Court, 2A Coombe Lane West, Kingston, Surrey KT2 7DX, UK; p.s@doctors.org.uk

Submitted 29 April 2004 Accepted 23 July 2004

\begin{abstract}
Aim and methods: A retrospective review was carried out of children undergoing peritoneovenous shunting for intractable ascites.

Results: 11 children, aged 3 months to 12 years (median 31 months) underwent peritoneovenous shunting over the past 17 years. The duration of ascites ranged from one month to 2.5 years (median two months). The primary pathology consisted of previous surgery in eight (three neuroblastoma, one renal carcinoma, one hepatoblastoma, one adrenal teratoma, one renal artery stenosis, and one diaphragmatic hernia), and cytomegalovirus hepatitis, lymphatic hypoplasia, and lymphohistiocytosis in one patient each. All patients had failed to respond to previous treatment including peritoneal drainage in six patients, diuretics in five, and parenteral nutrition in five. There were no intraoperative problems. Postoperative complications included pulmonary oedema in three patients, shunt occlusion in three, infection in two, and wound leakage in one. Ascites resolved after shunting in 10 patients. Five shunts were removed one to three years after insertion without recurrence of ascites. Three others are free of ascites with shunts in place for less than one year postoperatively. Three children died from their underlying disease: two after resolution of ascites (neuroblastoma) and one in whom the ascites failed to resolve (lymphohisticytosis). Conclusions: Peritoneovenous shunting is an effective treatment for symptomatic intractable ascites in children (10 of 11 successful cases in this series). Elective removal of the shunt after one year is recommended.
\end{abstract}

A scites in the adult population is largely related to alcoholic cirrhosis and malignancy. Peritoneovenous shunting in adults is well reported in the literature but there is little long term follow up as most succumb to their underlying disease. ${ }^{1-9}$ Ascites in children is more often related to previous surgery or congenital abnormalities of the lymphatic system and the potential for long term survival is much greater. There is little published information on the use and outcome of peritoneovenous shunts in children. ${ }^{10-12}$

\section{METHODS}

A retrospective review was carried out of the case notes of 11 children who underwent peritoneovenous shunting for intractable ascites over a 17 year period (1984-2001). The vascular ends of all shunts were placed in the atrium. All patients under 18 years of age who had peritoneovenous shunting for intractable ascites during the study period were included. Data collected included demographic details, cause and duration of ascites, age at operation, duration of follow up, and outcome.

\section{RESULTS}

The 11 children were aged 3 months to 12 years (median 31 months) (table 1). Eight had undergone previous abdominal surgery: three resections for neuroblastoma, one resection for hepatoblastoma, one adrenalectomy for adrenal teratoma, one auto-transplantation for renal artery stenosis, and one repair of recurrent diaphragmatic hernia. One child had previous surgery for necrotising enterocolitis although the ascites was attributed to cytomegalovirus hepatitis. One child had lymphatic hypoplasia and another had haemophagocytic lymphohistiocytosis. The duration of ascites before surgery ranged from one month to 2.5 years. All children were symptomatic ( $\geqslant 1$ of: decreased immobility, respiratory embarrassment, nausea, vomiting, or anorexia) and had failed to respond to medical management, which included paracentesis in six, diuretics in six, and dietary modification including parenteral nutrition in five. Despite the use of parenteral nutrition it is our experience that these children continued to produce large volumes of ascitic fluid.

Shunts were inserted under general anaesthesia in all cases. Denver shunts were used in 10 patients; one child had an initial Holter type shunt, which failed and was replaced after 12 days by a Leveen shunt. Access to the venous circulation was via the internal jugular vein in 10 and the saphenofemoral route in two.

There were no intraoperative complications. Early postoperative complications included transient pulmonary oedema in three patients, two of whom had had episodes before shunting and in the third it followed pumping of the shunt. Blockage of the shunt occurred in three, the Holter shunt described above and two of the Denver shunts; one resolved with pumping of the shunt, and the other required flushing of the shunt under general anaesthesia. Infection occurred in two patients, with positive cultures of the peritoneal fluid postoperatively in one. Both responded to intravenous antibiotics. One patient had postoperative leakage of ascitic fluid from the abdominal wound, which settled spontaneously. One child developed a late complication of a painful varix in the previously ligated saphenous vein eight years after shunt removal.

Ascites resolved after shunting in 10 of the 11 children (including the child who required initial shunt replacement). In these 10 patients total symptomatic improvement was achieved. Five children have had their shunt removed one to three years after insertion without recurrence of ascites. Three others are still free of ascites less than one year postoperatively. Three children have died from their underlying disease with shunts in place, two with neuroblastoma after resolution of ascites and the third with lymphohistiocytosis in whom the ascites failed to resolve. 


\begin{tabular}{|c|c|c|c|c|c|c|c|}
\hline Diagnosis & $\begin{array}{l}\text { Age } \\
\text { (months) }\end{array}$ & $\begin{array}{l}\text { Duration of ascites } \\
\text { (months) }\end{array}$ & Medical treatment & $\begin{array}{l}\text { Outcome of } \\
\text { ascites }\end{array}$ & Complication & $\begin{array}{l}\text { Shunt } \\
\text { removed }\end{array}$ & Surviva \\
\hline Neuroblastoma & 31 & 4 & $\begin{array}{l}\text { Diuretics } \\
\text { Diet } \\
\text { Drainage }\end{array}$ & Resolved & Varix & Yes & $\mathrm{A}+\mathrm{W}$ \\
\hline Neuroblastoma & 23 & 1 & Drainage & Resolved & Blockage & No & Died \\
\hline Neuroblastoma & 78 & 1 & & Resolved & None & No & Died \\
\hline Hepatoblatoma & 22 & 1 & Diuretics & Resolved & Infection & Yes & $A+W$ \\
\hline Renal carcinoma & 32 & 2 & Drainage & $\begin{array}{l}\text { 2nd shunt } \\
\text { Resolved }\end{array}$ & Leak & Yes & $A+W$ \\
\hline Adrenal teratoma & 36 & 1.5 & Drainage & Resolved & None & No & $A+W$ \\
\hline $\begin{array}{l}\text { Renal artery } \\
\text { Stenosis }\end{array}$ & 13 & 2 & $\begin{array}{l}\text { Diuretics } \\
\text { Diet } \\
\text { Drainage }\end{array}$ & Resolved & None & No & $\mathrm{A}+\mathrm{W}$ \\
\hline Diaphragmatic hernia & 19 & 2 & $\begin{array}{l}\text { Drainage } \\
\text { Diet }\end{array}$ & Resolved & None & Yes & $A+W$ \\
\hline Hepatitis & 3 & 1.5 & $\begin{array}{l}\text { Diuretics } \\
\text { Diet } \\
\text { Draingae }\end{array}$ & Resolved & $\begin{array}{l}\text { Pulmonary oedema } \\
\text { Infection }\end{array}$ & Yes & $\mathrm{A}+\mathrm{W}$ \\
\hline Lymphatic hypoplasia & 146 & 30 & $\begin{array}{l}\text { Diuretics } \\
\text { Diet }\end{array}$ & Resolved & $\begin{array}{l}\text { Pulmonary oedema } \\
\text { Blockage }\end{array}$ & No & $A+W$ \\
\hline Lymphohistiocytosis & 54 & 2 & Diuretics & Persisted & Pulmonary oedema & No & Died \\
\hline
\end{tabular}

\section{DISCUSSION}

The symptoms of ascites, which include anorexia, nausea, vomiting, pain, and respiratory embarrassment may be severe and disabling. Medical treatment of ascites with diuretics depletes the circulating volume in an attempt to draw fluid from the peritoneal cavity back into the circulation. Paracentesis removes the excess fluid from the peritoneal cavity providing good temporary relief but the fluid discarded is rich in electrolytes, protein, and white cells. Repeated paracentesis and diuretics may leave the patient hypovolaemic and nutritionally depleted..$^{4-613}$ The aim of peritoneovenous shunting is to return the fluid to the circulation; it does not change the underlying disease process but rather improves the haemodynamic status. ${ }^{14}$ Successful resolution of ascites produces relief from nausea and vomiting and permits removal of dietary restrictions that promotes improved enteral intake, which combined with the recirculation of ascitic fluid leads to an overall improvement in the nutritional status of the patient. In common with adult series we noted a rapid improvement in the patients overall wellbeing after shunting. ${ }^{13}$

The first description of the use of a prosthetic peritoneovenous shunt was by Smith in 1962 using a Spitz Holter valve. ${ }^{15}$ Although initially successful they tended to block, as shown in the one patient in our series in which it was used. In 1966 Hyde described his shunt designed specifically for the drainage of ascites, although he later admitted faults in the design that also led to a tendency to block. ${ }^{6}{ }^{16}$ The success of the Leveen shunt presented in 1974 renewed interest in peritoneovenous shunting. ${ }^{13}$ In the discussion that followed Waddel described his experience with the Denver shunt published later in 1979 by Lund and Newkirk. ${ }^{17}$ The principle behind these shunts is that ascitic fluid flows down a pressure gradient from the peritoneal cavity to the venous circulation. A valve mechanism prevents back flow of blood if the venous pressure rises above the intra-abdominal pressure. The valve chamber in the Denver shunt lies in the subcutaneous tissue and can be manually compressed both to promote flow and to relieve blockage. Denver shunts are therefore less prone to blockage and thus have largely replaced other designs as the shunt of choice in the treatment of ascites. ${ }^{3-10} 14$ Patients with symptomatic ascites should be considered for shunting after failure of at least two weeks intensive medical treatment, with depletion of extracellular fluid volume without reduction of ascites or rapid reaccumulation after. ${ }^{14}{ }^{16}$ Patients must be shown to be free from peritonitis before shunt insertion. ${ }^{51418}$ Contraindications include loculation of ascites, free blood, and a protein content of greater than $45 \mathrm{~g} / \mathrm{l}$ in the ascitic fluid, all of which prevent free flow and increase the risk of blockage. ${ }^{18}$ Congestive cardiac failure, severe cardiac disease, and renal failure all impair the handling of the increased plasma volume $^{518}$ and are further contraindications. Coagulopathy, gastrointestinal bleeding, and hepatic encephalopathy are also contraindications as all worsen with shunting. ${ }^{571418}$ Preoperative investigation must include microbiological and biochemical analysis of the peritoneal fluid, as well as basic blood tests including packed cell volume, coagulation profile, and liver function tests.

The routine postoperative use of diuretics has been recommended in adults, but we did not find this necessary in children without pre-existing cardiac disease and would recommend careful monitoring and use as clinically indicated. 467913 . Daily pumping of the shunt chamber is recommended to promote flow and to detect, prevent, and relieve blockage. ${ }^{59}$ Postoperative weight and urine output should be monitored, with a lack of diuresis leading to suspicion of shunt failure. Packed cell volume, haemoglobin, coagulation, and electrolytes should be monitored, with the peak of maximum haemodilution occurring in the first 48 hours. ${ }^{45}$ The routine use of perioperative antibiotics is recommended by some authors. ${ }^{514}$ Although there are no reports of fatalities in children, tumour emboli, fluid overload, and disseminated intravascular coagulation have all resulted in deaths in adults. ${ }^{3-7} 1418$ Discarding some ascitic fluid at operation can reduce the risk of fluid overload but the abdomen should not be drained completely, as patency of the shunt requires some flow. ${ }^{3}{ }^{4}{ }^{14}$ High central venous pressure will reduce flow, although pumping the chamber and abdominal compression may overcome this. ${ }^{10}{ }^{13}$

Infusion of ascitic fluid into the circulation dilutes the clotting elements, activates coagulation, and may cause disseminated intravascular coagulation. ${ }^{6}$ Although disseminated intravascular coagulation has not been reported in children undergoing peritoneovenous shunting, immediate ligation of the shunt would be recommended in such cases. ${ }^{6}$

Blockage of the shunt should be suspected if there is reaccumulation of fluid. It may be relieved by pumping the chamber or percutaneous flushing. Shunt infection may 
respond to intravenous antibiotics although removal may be necessary. ${ }^{513}$ Ascitic fluid leak from the abdominal wound has been reported. ${ }^{3469}$ Careful closure of the wound and reducing the intra-abdominal pressure by drainage of the fluid should reduce this complication.

Elective removal of the shunt has not previously been described. A few patients have been described in whom ascites did not recur after removal or verigeid blockage of the shunt. ${ }^{413} 19$ Ascites after retroperitoneal surgery was the underlying cause in eight of our 11 patients and is probably attributable to direct damage to lymphatic channels, which is recoverable. Also, the presence of a shunt carries the risk of infection, and we therefore recommend elective removal after one year.

In 10 of 11 patients in our series, ascites resolved leading to total symptomatic resolution with few complications. We have shown that peritoneovenous shunting in children is safe and successful and recommend the use of the Denver shunt early in the management of symptomatic ascites unresponsive to aggressive medical treatment.

\section{Authors' affiliations}

P Sooriakumaran, H F McAndrew, E M Kiely, L Spitz, A Pierro, Great Ormond Street Hospital for Children, London, UK

Funding: none.

Conflicts of interest: none declared.

\section{REFERENCES}

1 Wickremesekera SK, Stubbs RS. Peritoneovenous shunting for malignant ascites. N Z Med J 1997; 110:33-5.
2 Edney JA, hill A, Armstrong D. Peritoneovenous shunts palliate malignant ascites. Am J Surg 1989;158:598-601.

3 Smith DA, Weaver DW, Bouwan DL. Peritoneovenous shunt for malignant ascites. An analysis of outcome. Am Surg 1989;55:445-9.

4 Soderlund C. Denver peritoneovenous shunting for malignant or cirrhotic ascites. Scand J Gastroenterol 1986;21:1161-72.

5 Gullstrand $\mathrm{P}$, Alwmark A, Borjesson B, et al. Peritoneovenous shunting for intractable ascites. Scand J Gastroenterol 1982;17:1009-12.

6 Hyde GL, Dillon M, Bivins BA. Peritoneal venous shunting for ascites: a 15 year perspective. Am Surg 1982;48:123-7.

7 Lund RH, Moritz MW. Complications of Denver peritoneovenous shunting. Arch Surg 1982;117:924-8.

8 Tyden G, Samnegard H, Thulinn L. Peritoneovenous shunting for intractable ascites. Acta Chir Scand 1982;148:597-600.

9 Osterlee J. Peritoneovenous shunting for ascites in cancer patients. $\mathrm{Br} J$ Surg 1980;67:663-6.

10 Chang JHT, Newkirk J, Carlton G, et al. Generalised lymphangiomatosis with chylous ascites treatment by peritoneo-venous shunting. J Pediatr Surg 1980;15:748-50.

11 Kerr RSC, Powis SJA, Ross JRY, et al. Peritoneovenous shunt in the management of paediatric chylous ascites. Br J Surg 1985;72:443-4.

12 Man DWK, Spitz L. The management of chylous ascites in children. J Pediatr Surg 1985;20:72-5.

13 Leveen HH, Christoudias G, Moon IP, et al. Peritoneo-venous shunting for ascites. Ann Surg 1974; 180:580-91.

14 Gleysteen JJ, Klammer TW. Peritoneovenous shunts: predictive factors of early treatment failure. Am J Gastroenterol 1984;79:654-8.

15 Smith AN. Peritoneocaval shunt with a Holter valve in the treatment of ascites. Lancet 1962;i:671-2.

16 Hyde GL, Eiseman B. Peritoneal atrial shunt for intractable ascites. Trans Am Soc Artif Intern Organs 1966;12:108.

17 Lund RH, Newkirk JB. Peritoneo-venous shunting system for surgical management of ascites. Contemp Surg 1979;14:31.

18 Fildes J, Narvaes GP, Baig KA, et al. Pulmonary tumor embolisation after peritoneovenous shunting for malignant ascites. Cancer 1988:61:1973-6.

19 Turner WW. Chylous ascites: resolution after Denver peritoneovenous shunt South Med J 1983;76:539. 